\title{
Judicial Review of Government Regulation Number 24 of 2016 Concerning Amendment to Government Regulation Number 37 1998 Concerning Land Deed Official Position Regulations
}

\author{
${ }^{1}$ Zelis Febriani ${ }^{*}{ }^{2}$ M. Ilwan, ${ }^{3}$ Kaharudin \\ ${ }^{1}$ Master of Law student, Faculty of Law, Mataram University, Indonesia \\ ${ }^{2,3}$ Lecture of Law Faculty Mataram University, Indonesia
}

\begin{abstract}
This research is to find out and understand the legal status of the delegation of government regulations to other government regulations and the juridical consequences of Government Regulation Number 24 of 2016 concerning Amendments to Government Regulation Number 37 of 1998 concerning Land Deed Official Position Regulations that are formed not in accordance with statutory regulations. This research is a normative legal research. Normative legal research is legal research that places law as a norm building system. The norm system in question is about the principles, norms, rules, and regulations. Using the legal approach and conceptual approach. The technique of collecting legal materials using document study techniques is then processed by legal materials and analyzed normatively prescriptive using deductive logic. Based on the results of the study it can be concluded that the legal status of the delegation of authority to form government regulations delegated from other government regulations is invalid, because government regulations are formed to carry out the law as it should, not to carry out the provisions of other government regulations. Juridical consequences of Government Regulation Number 24 of 2016 concerning Amendments to Government Regulation Number 37 of 1998 concerning Land Deed Official Position Regulations that are formed not in accordance with statutory regulations are null and void because they cannot provide legal certainty. This is because the formation of these government regulations is not in accordance with the principles of establishing the rules of law stipulated in Law Number 12 of 2011. The impact of this Government Regulation can be revoked because it does not comply with the principles of the formation of laws and regulations.
\end{abstract}

Keywords: Delegation, Authority, Government Regulations.

\section{Introduction}

The formation of laws and regulations is one of the legal developments, in addition to the application, law enforcement, and understanding of the law itself. The development of law implemented comprehensively includes the legal substance, legal institutions and legal culture and is accompanied by strict enforcement of the law, consistent with upholding human rights, will be able to actualize the legal function as a means of reform and development as well as an instrument for solving problems fairly and as regulator of people's behavior to respect the law. ${ }^{1}$

According to Bagir Manan "the function of the legislation consists of two functions, namely internal functions and external functions. This internal function is more related to the existence of laws and regulations referred to in the legal system. Internally, laws and regulations carry out the functions of creating law (rechts chepping), legal reform, integration and legal certainty. While the external function consists of a change function, a stabilization function and an ease function".

Law Number 12 of 2011 concerning Formation of Regulations and Regulations is based on the idea that the State of Indonesia is a state of law. As a rule of law, all aspects of life in the social, national and state fields

\footnotetext{
${ }^{1}$ Departemen Hukum dan Hak Asasi Manusia RI Badan Pembinaan Hukum Nasional Pusat Penelitian dan Pengembangan Sistem Hukum Nasional, Laporan Ompendium Bidang Hukum Perundang-Undangan, Jakarta, 2008, p. 29.

${ }^{2}$ Bagir Manan, Pertumbuhan dan Perkembangan Konstitusi Suatu Negara, Mandar Maju, Bandung, 1995. p. 41
} 
including government must be based on laws that are in accordance with the national legal system. The national legal system is a law that applies in Indonesia with all its elements that support one another in order to anticipate and overcome the problems that exist in social, national and state life based on the Pancasila and the 1945 Constitution of the Republic of Indonesia.

In general, Law Number 12 of 2011 concerning Formation of Regulations and Regulations contains systematically compiled main materials. One of the material that is regulated is about the formation of government regulations. The definition of government regulations referred to in this law is the statutory regulations established by the President to carry out the law as it should. ${ }^{3}$

Government regulations are one type of legislation in Indonesia. Government regulations contain the material is to carry out the law as it should. From the construction of the material content it can be understood that the function of government regulations is as an instrument to hold further regulations to implement the law. In a law formed by the legislature is often found mandate to form a government regulation in the formulation of norms contained in a law, as well as Government Regulation Number 24 of 2016 concerning Amendments to Government Regulation Number 37 of 1998 concerning Land Deed official Position Regulations that should be formed with the delegation of Law Number 5 of 1960 concerning Basic Agrarian Principles.

Government Regulation Number 24 of 2016 concerning Amendment to Government Regulation Number 37 of 1998 concerning Land Deed Official Position Regulation is a delegation of Government Regulation Number 24 of 1997 concerning Land Registration which should according to the delegation technique in Appendix II of UUP3, delegation of authority can be carried out from the legislation higher invitation to lower. ${ }^{4}$

In addition, according to Law Number 12 of 2011 concerning Formation of Regulations and Legislation, delegation of authority to regulate further equivalents can also be made from one Act to another Act, from Provincial Regulations to Other Provinces, or from Regulations Regency/City Regions to Other Regency/City Regulations ${ }^{5}$. While in Article 7 paragraph (3) government regulation number 24 of 1997 concerning land registration delegates the formation of government regulation number 37 of 1998 concerning Land Deed Official position regulations as amended by Government Regulation Number 24 of 2016. This means that there is a delegation of authority to stipulate further provisions which not in accordance with Law Number 12 of 2011 concerning Formation of Regulations and Regulations.

\section{Research Methods}

This research is categorized as Normative legal research. In this research, the approach used is the Statute Approach and Conceptual Approach. The type of data and legal materials used in this study are the laws and regulations relating to the problem under study, among others: Law Number 12 of 2011 concerning Formation of Laws and Regulations, Law Number 5 of 1960 concerning Basic Rules Basic Agrarian Affairs, Government Regulation Number 24 of 1997 concerning Land Registration, Government Regulation Number 37 of 1998 concerning Land Deed Official Position, Government Regulation Number 24 of 2016 concerning Amendment to Government Regulation Number 37 of 1998 concerning Land Deed Official Position.

Based on the above sources, the legal material collection technique used in this study was conducted with a literature study of legal materials, both secondary, primary and tertiary legal materials. Analysis of legal materials used in research using the method of interpreting the law also uses the principles of the law, the Lex Superior Derogat Legi Inferior Principle, the principle of legal interpretation which states that the higher law (lex superior) overrides the lower law (lex inferior) which is analyzed in a manner prescriptive normative by using deductive logic, namely drawing conclusions from things that are general to things that are specific.

\footnotetext{
${ }^{3}$ Article 1 number 5 of Law Number 12 of 2011 concerning Formation of Regulations and Regulations

${ }^{4}$ CHAPTER II letter A number 198 Attachment II of Law Number 12 of 2011 concerning Formation of Regulations and Regulations.

${ }^{5}$ CHAPTER II letter A number 199 Attachment II of Law Number 12 of 2011 concerning Formation of Regulations and Regulations.
} 


\section{Results and Discussion}

\section{Legal Status of Delegation of Authority from Government Regulations to Other Government Regulations.}

Legislation is a written regulation that contains generally binding legal norms and is formed or established by a state institution or an authorized official through the procedures set out in a statutory regulation ${ }^{6}$. Legislation generally does not contain detailed or detailed regulatory provisions, so that in order to implement these provisions it is necessary to make further arrangements in a legal set of similar or lower Regulations.

An order of a statutory regulation to make further arrangements for an institution in the form of a similar legal instrument or legal instrument which is lower than the relevant statutory regulation, an order to form further provisions in the science of legislation is called the delegation of authority. This delegation of authority is generally given to the proponent to make further legal arrangements so that the provisions stipulated in the relevant law can be implemented accordingly. The order for the establishment of further regulations to the State / government institution is a delegation of authority.

Delegation means handover, in the form of delegation of responsibility to others, while authority is the right and power to act, the power to make decisions, the power to govern or carry out legal functions that may not be carried out ${ }^{7}$. Delegation is the delegation of authority from a lower official with full responsibility and accountability to the recipient of the delegation ${ }^{8}$. Delegation is delegation of authority to form laws and regulations which are carried out by higher laws and regulations to lower laws and regulations, whether delegations are stated explicitly or not ${ }^{9}$. Delegation of authority to form laws and regulations is the transfer or delegation of responsibility to other people for the right and power to act and the granting of authority to other parties to form a set of laws and regulations, in other words Delegation of authority to form legislation, is delegation. or granting some authority to the institution, Ministry/non-ministerial Government, Provincial Regional Government and Regency/City Government in the context of establishing a legal instrument to implement a statutory regulation.

Delegation of authority in the formation of legislation, can be divided into two forms, namely Delegation of Attribution and Delegation Authority. Delegation of Attribution Authority is the granting of authority to form the Statutory Regulations granted by the Basic Law or the Law to a State Institution/government. Related to the source of authority in the view of Philipus M Hadjon in terms of how to obtain authority over two main ways namely attribution and delegation and sometimes the mandate ${ }^{10}$.

Sources of authority in the formation of statutory regulations The formation of legislation is distinguished as stated by A Hamid S. Attamimi, Bagir Manan and I.c Van Der Vlies consisting of delegation and delegation authority ${ }^{11}$. With regard to obtaining authority according to A Hamid S Attamimi, it is distinguished from attribution and delegation authority. Understanding related to the authority includes:

1. Attribution authority is the confiscation of (new) authority by the constitution/gronwet or by the forming of wet which is given to a state organ, either existing or newly formed for it.

2. Delegation authority is the delegation of authority to form legislation from the delegans (the original authority that delegates members) to the delegates (who accept the delegation) at their own responsibility.

Attribution and delegation of authority according to Bagir Manan are distinguished as follows ${ }^{12}$ :

\footnotetext{
${ }^{6}$ Article 1, number 2 of Law 12 of 2011 concerning Formation of Regulations and Regulations.

${ }^{7}$ Kamus Besar Bahasa Indonesia, Pusat Bahasa Indonesia.

${ }^{8}$ Article 1 Number 23 of Law Number 30 Year 2014 concerning Government Administration

${ }^{9}$ Maria Farida Indrati Soeprapto, Hal-hal Khusus Dalam Perundang-undangan, Jakarta, 2009.

${ }^{10}$ Philipus M.Hadjon, 2005, Pengantar Hukum Administrasi Indonesia, (Introduction The Indonesian Administrative Law), Gadjah Mada University Press, Yogyakarta, p. 130.

${ }^{11}$ Bagir Manan, 2000, Wewenang Provinsi Kabupaten dan Kota Dalam Rangka Otonomi Daerah,,Makalah Pada Seminar Nasional FH Unpad (Selajutnya disebut Bagir Manan V), Op.cit, p. 206-214, A.Hamid.S.Attamimi II,Op.cit, p. 347-352, Ic. Van Der Vlies, Op.cit, p. 78-79.

${ }^{12}$ Bagir Manan IV, Op.cit, p.209-210.
} 
1. Attribution exists if the constitution or law (in the formal sense) gives an entity with its own power and its own (independent) responsibility to make / form laws and regulations.

2. Delegation exists if an entity that has attributive authority (the authority to independently make laws and regulations) devolves to other bodies the authority to form laws and regulations on its own responsibility.

Understanding of the meaning of attribution and delegation according to Ic. Van Der Vlies are as follows ${ }^{13}$ :

1. Attribution is the creation of authority and giving to an organ.

2. Delegation is understood by people as the delegation of authority so that the party that gets the authority (delegataris) will carry it out on their own responsibility

Understanding attribution, delegation and mandate according to Philip M Hadjon, A Hamid S Attamimi, Bagir Manan, Ic Van Der Vlies, in the Dictionary of Legal Terms Fockema Andreae Dutch-Indonesian and Black's Law Dictionary can be concluded that in attribution is created an authority, delegation is handed over an authority whereas in the mandate there is no creation or surrender of authority.

In connection with the formation of laws and regulations, the meaning of attribution in the formation of legislation contains elements of:

1. Creation of (new) authority to make laws and regulations;

2. The authority is granted by the legislators or legislators to an institution;

3. Institutions that accept authority are responsible for the exercise of that authority.

Provisions in the Academic Paper of Law Number 30 Year 2014 concerning Government Administration show that there is a basis for official authority by emphasizing the existence of juridical implications related to responsibility, accountability and competence of government authority which can be distinguished into ${ }^{14}$ :

a. Original legislators, namely the People's Consultative Assembly as constitution drafting, the Government together with the House of Representatives in the drafting of the Law and the Regional Government together with the Regional People's Representative Council in drafting Regional Regulations.

b. Delegated legislators, for example the President who, based on the provisions of a law, has the authority to issue Government Regulations as an elaboration of the Law in which there is the creation of authority for the state administrative agencies underneath, different in attribution, delegation as a source of authority, constitutes the delegation of authority from an instarisi or state administration official who has obtained an attributive governmental authority to another state administration agency or official.

c. In addition to the two forms above, there is one more form which is also known in the state administration which is related to the distribution of authority, namely the mandate. In a mandate, a governmental authority is exercised by a mandator on behalf of and responsibility of the creditor.

Starting from the difference of delegation and mandate as explained by Philipus M Hadjon, R.J.H.M. Huisman and the provisions in Law Number 30 of 2014 concerning Government Administration can be put forward as follows: Philipus M Hadjon's opinion sees the difference in delegation and mandate of delegation procedures, responsibilities and accountability and the possibility of the giver using that authority again, while R.J.H.M. Huisman sees from a theoretical point of view related to the transfer and transfer of responsibilities. The provisions in the provisions of Law Number 30 Year 2014 concerning Government Administration distinguishes attribution, delegation and mandate by looking at the sources of authority, responsibility and accountability. The meaning of the above opinion appears to be the difference in character in the source of authority in the formation of legislation and sources of government authority. The source of authority in the formation of legislation consists of attribution and delegation while in government authority

\footnotetext{
${ }^{13}$ Ic. Van Der Vlies, Op.cit, p. 78-79.

${ }^{14}$ Kementrian Pendayaan Aparatur Negara, 2013, Naskah Akademik Undang-Undang Administrasi Pemerintah, Jakarta,
} 
consists of attribution, delegation and mandate. The authority of government places more emphasis on the aspects of accountability and responsibility as the implications of the exercise of authority.

An understanding related to the delegation of authority was also raised by Jimly Asshiddiqie, stating that the delegation of authority was the authority to regulate further explicitly delegated by the main legislator to the secondary legislator, the process of delegating the authority of regulation is what is called the delegation of authority ${ }^{15}$. Based on the principle of delegation of legal norms that are of an implementation nature are considered invalid if they are formed without being based on delegation of authority from higher legislation. The authority to form laws and regulations must be explicitly contained in the laws and regulations as a provision for delegation.

Based on this understanding delegation means a shift in competence and even includes research, the release and acceptance of an authority, both of which are at the will of the party who surrenders the authority. The delegating party must have an authority that is not currently used while the delegation recipient also has the authority and is extended with what is delegated. The basis of the authority of the forming agency and the contents of the content is a benchmark in the delegation in the sense that not all material content must be formally regulated in the law, but the relevant law can also delegate its regulation to the lower legislation (delegated legislation).

According to Bagir Manan the restrictions in delegation arrangements are as follows ${ }^{16}$ :

1. There must be no delegation of arrangements regarding matters which expressly or which by their nature must be regulated in certain statutory regulations, for example the Constitution, the People's Consultative Assembly or the law;

2. There must be no general delegation of arrangements. Each regulatory delegation must clearly state the points that will be regulated in the legislation of the delegation. For example it is mentioned regarding the arrangement of organizational structure, work procedures and so on. In the provisions of delineation, it is not enough just to mention. For example, "matters which are not sufficiently regulated in this law, are further regulated in implementing regulations;

3. Each regulatory delegation must clearly state the form of the legislation of the delegation. For example Government Regulations, Ministerial Decrees and so on. The delegation must not only state, for example, "Determination of places of detention, not detention centers, is further regulated by statutory regulations".

Based on the description above, it can be understood that the delegation needs to be considered:

a. There should be no general delegation of arrangements. Each delegation in the arrangement must state explicitly the points regulated in the legislation of the delegation. For example, it is mentioned regarding the organizational structure of work procedures and so on. In the provisions regarding delegation, if only mentioning for example, matters that have not been sufficiently regulated in this Law will be further regulated in implementing regulations. (Government Regulations, Presidential Regulations, Governor Regulations and so on).

b. Each regulation delegation must clearly state the form of the legislation delegated.

Government regulations are one type of legislation in Indonesia. The 1945 Constitution of the Republic of Indonesia has granted full rights to the President to stipulate government regulations in order to implement the law accordingly. Government regulations contain the material content to carry out the law as it should ${ }^{17}$. Article 24 of Attachment II of Law Number 12 of 2011 concerning the Formation of Laws and Regulations also confirms that the consideration or brief description of the main points of consideration and reasons for the formation of government regulations is sufficient to contain a consideration that contains a brief description of the need to implement the provisions of the article or several articles of the Law that instruct the formation of these government regulations by designating articles or several articles of the Law that instruct them to be formed ${ }^{18}$.

\footnotetext{
${ }^{15}$ Jimly Asshiddiqie, 2006, Perihal Undang-Undang, Konstitusi Press Jakarta, p. 147-148.

${ }^{16}$ Bagir Manan I, Op.cit, p. 45-46.

${ }^{17}$ Article 12 of Law Number 12 of 2011 concerning Formation of the Formulation of Regulations and Regulations.

${ }^{18}$ point 24 Appendix II of Law Number 12 of 2011 concerning Formation of Formation of Regulations and Regulations
} 
From the construction of the content and consideration material, it can be understood that the function of government regulations is as an instrument to make further arrangements to implement the law. The function of government regulations is to carry out the following matters ${ }^{19}$ :

a) Further regulation of the provisions in the Law which expressly calls it. This function is in accordance with the provisions in Article 5 paragraph (2) of the 1945 Constitution of the Republic of Indonesia. In this case government regulations must implement all provisions of a law that explicitly instructs (delegation) to be regulated further by Government Regulation.

b) Carrying out further provisions in other provisions in the law governing although not explicitly mentioning it. If a problem in a law requires further regulation, while the provisions do not explicitly mention to be regulated in a government regulation, the government regulation can regulate it further as long as it is a further implementation of the law. This is in line with the explanation of Law Number 12 of 2011 concerning Formation of Legislation in Article 12 which states that what is meant by carrying out the law properly is the establishment of government regulations to carry out law orders or to carry out laws as long as necessary by not deviating from the material stipulated in the Act concerned.

Based on the description above, the Government Regulation is a statutory regulation determined by the President to carry out the law accordingly. The phrase running the law as it should be according to further elaboration in the explanation of Law Number 12 of 2011 concerning the Formation of Regulations of the Law, which is either expressly ordered by the Act or not expressly ordered by the Act as long as necessary to carry out the Act Act and do not deviate from the relevant law.

However, in the formation of Government Regulations that are ordered (delegated) from other Government Regulations, of course not in accordance with the definition, material content and function of Government Regulations. Government Regulations cannot be formed on the basis of orders (delegations) from Government Regulations to other Government Regulations or to carry out the provisions of the Article or several articles ordered in the Government Regulation. equivalent delegation from Government Regulations to other Government Regulations such as Government Regulation Number 37 of 1998 concerning Land Deed Official Position Regulations and Government Regulation Number 24 of 2016 concerning Amendments to Government Regulation Number 37 of 1998 concerning Land Deed Official Position Regulations contained in philosophical consideration both philosophically, sociological and juridical states that the Government Regulation was formed in order to carry out the provisions in Article 7 paragraph (3) government regulations Number 24 of 1997 concerning Land Registration. In Article 7 paragraph (3) explains that "Regulation of Land Deed Official Position as referred to in paragraph (1) is regulated by a separate Government Regulation. The phrase governed by a separate Government Regulation in this paragraph constitutes a delegation of further regulatory authority (delegation) related to Land Deed Official office regulations governed in a separate Government Regulation.

legal status of the delegation of authority equivalent from government regulations to other government regulations contained in Government Regulation Number 37 of 1998 concerning Land Deed Official Position and Government Regulations Number 24 of 2016 concerning Amendment to Government Regulation Number 37 of 1998 concerning Land Deed Official Position Regulation is invalid because it is not in accordance with the provisions contained in Law No. mor 12 of 2011 concerning Formation of Laws and Regulations both in type, hierarchy and material content of the formation of government regulations, where all the formation of laws and regulations both government regulations, laws and other laws and regulations must comply with and adhere to the principles of the formation of laws and regulationsinvitation.

Based on the description above, the legal status of the delegation of equal authority from government regulations to other government regulations contained in Government Regulation Number 37 of 1998 concerning Land Deed Official Position Regulation and Government Regulation Number 24 of 2016 concerning Amendment to Government Regulation Number 37 of 1998 concerning Regulations The position of Land Deed Official is invalid because it is not in accordance with the provisions contained in

${ }^{19}$ Maria Farida Indrati Soeprapto, Ilmu Perundang-Undangan, Kanisius, Yogyakarta, p.115 
Law Number 12 of 2011 concerning Formation of Regulations of Laws both in terms of type, hierarchy and content of the formation of government regulations, where all the formation of laws and regulations both government regulations, laws and other laws and regulations must comply with and adhere to the principles of the formation of laws and regulations.

\section{Juridical Consequences of Government Regulation Number 24 of 2016 concerning Amendment to Government Regulation Number 37 of 1998 concerning Land Deed Official Position Regulations which are formed not in accordance with the laws and regulations}

The making of the rule of law is actually intended so that the rule can be upheld maximally, if the rules that have been made can be upheld maximally then it is hoped that it will be able to create two things namely justice and legal certainty. In order to achieve these two objectives, teachings and instruments were created that can be used to design, apply and test a rule of law.

One rule of law that is made, even though it is intended to solve the problem, is certainly not possible to touch all sides as a whole. For this reason a rule of law needs to be detailed from general rules to technical rules. This is where the types and types of legal rules are made. Every rule of law is made in stages and each level has its own content material. With the existence of clear rules, it is expected to close the arena of choice which results in unclear application of the law.

The problem that will then arise is when there is an inconsistency or overlap in the arrangement between the lower legal rules and the higher legal rules or equal legal rules due to improper delegation contained in the Act. This of course can trigger legal problems plus the problem of delegation which results in overlapping legal regulations which cannot be used as a reason for conducting a judicial review ${ }^{20}$.

The benefit of consistent delegation of laws to the laws and regulations below is actually to guarantee legal certainty which avoids overlapping rules. It is important to consider that the lower level of the rule of law should not conflict with the higher level of the rule of law, so that the rule of law should be ordered in a gradual manner and gradually be delegated to a level below that in accordance with the hierarchy of statutory regulations so that each rule of law does not regulate more than the delegated one. In addition, the guideline function of higher rules is to produce rules that are increasingly downward in detail, rigid, technical and procedural so as not to open an arena of choices that can be misused and the legal rules that have been made can be maximally enforced.

If Government Regulation Number 24 of 2016 concerning Amendment to Government Regulation Number 37 of 1998 concerning Land Deed Official Position Regulation is applied retroactively, it will be reviewed from several legal aspects, including:

\section{According to Criminal Law}

Accountability is one part of the elements of a system of rules in morals, religion and law. This system of rules can be broad and diverse, for example civil law, criminal law, and moral rules. The similarity of the three things is a set of rules about the behavior followed by a certain group. So the system that gave birth to the conception of the responsibility of the answer is a normative system.

Based on the origin of the normative system that gave birth to the conception, the writer analyzes criminal liability. What is meant by being responsible for committing a criminal act, by quoting Alf Ross's opinion, Roeslan Saleh gave the answer that those responsible for a criminal act means that the person concerned can be legally subject to a crime because of that act. That the criminal can be legally imposed means that for the action there are rules in a particular legal system, and the legal system applies to this act. In short it can be said that this action is justified by the legal system. This is the basic concept.

Furthermore, Ross is of the opinion that the responsibility is stated by the existence of a relationship between the reality which is a prerequisite and the legal consequences required. The relationship between

${ }^{20}$ Hoesein, Zainal Arifin, Judicial Review di Mahkamah Agung RI (tiga dekade pengujian peraturan perundangundangan), Jakarta:Rajawali Press, p. 197 
the two is neither natural nor causal, but is established by the rule of law. So the responsibility is a statement of a legal decision ${ }^{21}$.

Furthermore, based on Moeljatno's view, Moeljatno concluded that to say that a person can be accounted for must fulfill the elements of criminal liability such as the following: Conducting criminal acts (nature against the law); Above a certain age able to be responsible; Having a form of error in the form of intentional or negligence and the absence of forgiving reasons ${ }^{22}$.

In both civil law and common law countries, criminal liability is generally negatively formulated. This means that in Indonesian criminal law, like other civil law systems, the Act precisely defines circumstances that can cause the maker to be irresponsible. Thus, what is regulated are the conditions which can cause the maker not to be convicted (strafuitsluitingsgronden) which for some is the reason for erasing the error. Whereas in the practice of justice in common law countries, a variety of general reasons are accepted or general reasons for the exclusion of liability are accepted.

Hart said, "If a legal system did not provide facilities allowed individually to give legal effects to their choices in such areas of conduct, it would fail to make one of the law's most distinctive and valuable contributions to social life." Thus the law is seen as failing to provide valuable input on social life, if it does not open up opportunities for offenders to explain why they cannot avoid criminal acts ${ }^{23}$.

In order to provide a complete picture, the following will be described regarding the elements of criminal liability, as follows.

\section{a. Criminal Acts}

Before discussing the elements of criminal offenses, it is better to first discuss the use of the terms and definitions of criminal acts. Among criminal law experts, the use of the term regarding this criminal act varies, there are those who use criminal events, criminal acts (Dutch language, namely strafbaar feit)

According to Moeljatno, a criminal act is an act that is prohibited by a legal regulation where prohibition is accompanied by threats (sanctions) in the form of certain crimes, for those who violate the act. It can also be said that a criminal act is an act that is prohibited and threatened by criminal law, provided that in the meantime it is remembered that the prohibition is directed at an act, (ie a condition or event caused by a person's behavior), while the threat of criminal is directed at a person who cause it to happen ${ }^{24}$.

According to J.E Jonkers, a criminal event is an unlawful act (wederrechttelijkheid) relating to intentional or wrongdoing done by a person who can be accounted for According to Vos, Criminal Acts are human behavior or behavior which by the laws and regulations are given criminal ${ }^{25}$.

Based on the descriptions above, then in terms of the use of the term criminal acts and the understanding of criminal acts the author agrees with Vos, which is more appropriate to use the term criminal act (strafbaarfeit) not a criminal act because in criminal liability it is not enough to only commit criminal acts but in addition there must be an error that is the principle that is not written that is not convicted without error. This is further emphasized in the Criminal Code concept which uses criminal acts.

\section{b. Elements of Criminal Acts}

The elements of criminal acts according to Moeljatno are: (a) acts, (b) that are prohibited (by law), (c) criminal threats (for those who violate prohibitions). From these elements, it can be explained that in terms of works it means that only human actions are prohibited, by the rule of law. While the threat of criminality

\footnotetext{
${ }^{21}$ Moeljatno. Pertanggung Jawab Pidana, Aksara Baru, Jakarta, 1987, p. 34-35

${ }^{22}$ Ibid. p. 164

${ }^{23}$ Kornelia A. Mandasari, "Pertanggungjawaban Pidana Tindak Pidana Terkait Pemberian Delegasi Kewenangan," Jurnal Mimbar Keadilan, vol. 14, no. 28, (Januari 2019): p.186

${ }^{24}$ Moeljatno, Asas-Asas Hukum Pidana, Rineka Cipta,Jakarta, 2008. p. 54-55

${ }^{25}$ A. Zainal Abidin Farid, Hukum Pidana I, (Jakarta: Sinar Grafika, 1995), p. 225
} 
illustrates that it is not necessary that the act is actually convicted. According to Vos, the elements of criminal offenses are; (a) human behavior, (b) threatened with crime, (c) in law regulation ${ }^{26}$.

Based on these formulations, a conclusion can be drawn, namely that the criminal act is a human act that is prohibited, contained in the Act, and threatened with criminal offenses for the perpetrators of the crime.

\section{c. Capable of being responsible}

The issue of the ability to take responsibility is very important, namely as a basis for mistakes. Legally there is no formal limit on this ability. When seen in the Criminal Code (KUHP), namely Article 44 paragraph (1) only formulates negatively, requiring when a person is deemed incapable of responsibility based on two reasons, namely (a) his soul is defective in his growth, (b) his soul disturbed due to illness. Furthermore, doctrinally, namely the ability to be responsible there must be two things, namely ${ }^{27}$ :

1. the ability to differentiate between good and bad deeds; which is in accordance with the law and which is against the law (reason);

2. The ability to determine his will according to his conviction about the good and bad actions of the earlier (will).

\section{d. Mistakes}

Mistakes relate to criminal liability, because the principle of criminal liability is the principle of culpability, which is not to be convicted without error. According to Jonkers in his statement about shuldbegrip (the concept of error) makes a division of three parts in terms of error, namely (1) in addition to deliberate or negligence (opzet of shuld); (2) including also the nature of breaking the law (de wederrechtelijkheid); (3) the ability to be responsible (de wederrechtelijkheid) ${ }^{28}$.

The above understanding, it seems that it is tucked into an element of unlawfulness contained in an element of error, if it is associated with a view of the definition of a criminal act (Strafbaarfeit), then the elements of the crime include both the elements of the act which are commonly called objective elements and elements the maker (actor) commonly called the subjective element. Because of the mixed elements of the act and the elements of the perpetrators, it can be concluded that the criminal act is the same as the conditions for imposing a crime, so it seems as if it is considered that if a crime occurs, then the perpetrators can be convicted $^{29}$.

\section{e. No Excuses For forgiveness}

In discussing there is no reason for forgiveness, first the reasons for criminal negation (strafuitsluitingsgronden) are discussed as well as the types of reasons for criminal negation ${ }^{30}$.

The reasons for criminal negation (Strafuitsluitingsgronden) in the Criminal Code are divided into two groups namely general and specific ${ }^{31}$. According to Article 44 paragraph (1) of the Criminal Code the person who caused the incident was not convicted because: (a) soul / mind that grew imperfectly, (b) soul disturbed by illness, which at the time of birth was healthy but was later afflicted with illness, such as insanity. If someone has an illness like the one above, his actions cannot be accounted for.

Based on the explanation above, there are several criminal law experts stating that the force of force can be a reason for forgiveness or justification, including the opinions of Van Hattun and Moeljatno, which states that in article 48 there are reasons for forgiveness, with the reason if the act was committed by people because of the influence of force, automatically the inner function cannot work normally due to pressures from the outside, so that person is forgiven for his mistakes ${ }^{32}$.

\footnotetext{
${ }^{26}$ Leden Marpaung, Unsur-Unsur Perbuatan Yang Dapat Dihukum, (Jakarta: 1991, Sinar Grafika,1991), p.4

${ }^{27}$ Moeljatno, Op.cit., p.165

${ }^{28}$ Roeslan Saleh, Perbuatan Pidana Dan Pertanggungjawaban Pidana, Dua pengertian Dasar Dalam Hukum Pidana, cetakan ketiga, (Jakarta: Aksara Baru, 1983), p. 81

${ }_{29}$ Muladi, dkk, Demokratisasi Hak Asasi manusia Dan reformasi Hukum Di Indonesia, (Jakarta: The Habibie Center, 2002), p.50.

${ }^{30}$ Mustafa Abdullah, dkk, Intisari Hukum Pidana, (Jakarta: Ghalia Indonesia, 1983), p.68.

${ }^{31}$ Ibid, p. 69-74

${ }^{32}$ Moeljatno,Op.cit., p.141-142
} 
Article 49 paragraph (1) of the Criminal Code forced or noodweer must meet several conditions, namely, (a) there must be an attack; (b) there is a defense; meaning that there must be a balance between the interests of the law being violated with the interests of the law being defended. Legal interests are defended only the body, honor, own property or others ${ }^{33}$.

Article 49 paragraph (2) noodweer exces/defenses that exceed the limits. The construction of the defense act in Article 49 paragraph (2) of the Criminal Code requires that the defense is caused by a severe mental shock. The defense is forced to go beyond the limits that are not caused by a great shock of the soul, not eliminate the criminal.

Article 50 of the Criminal Code (Wettelijk voorschrif)/regulations of the Law. In this case, it is determined that no criminal penalty is imposed by a person who commits an act to implement a statutory law. The meaning of the determination, that is what is ordered by a law or the authority given by a law to do something cannot be considered as a criminal event. In this case there is a justification, because what is done by someone is right he did because of an order from the law.

Article 51 (Position Order (ambtelijk bevel)) Article 51 paragraph (1) states: Anyone who commits an act to carry out a position order given by an authorized authority is not convicted.

Article 51 Paragraph (2) states: A position order without authority, does not cause criminal offense, except if the one being ordered, in good faith thinks that the order was given with authority, and its implementation is included in its work environment.

The reason for the special criminal offense, in this case only applies to certain offenses such as Article 166 of the Criminal Code linked to Articles 165 and 164, cannot be applied to persons who due to family relations between someone who knows the commission of a crime and the person who commits the crime ${ }^{34}$.

\section{According to Civil Law}

Civil law is all the principal laws governing individual interests and the relationship between legal subjects. in Article 1 of the Civil Code, Civil Law is an interpersonal law governing the rights and obligations of individuals from one another in family relations and in social relations. Civil law is also called private law. Juridical consequences in the formation of Government Regulation Number 24 Year 2016 concerning Land Deed Official Position Regulation which was formed not in accordance with the statutory regulations according to civil law is not retroactive. Determination of retroactivity is not contained in legislation containing provisions that place a concrete burden on individuals or communities ${ }^{35}$.

\section{According to Constitutional Law}

In forming a statutory regulation must be carried out based on the principle of the formation of the statutory regulation. Hamid Attamimi argues that "the principles of the formation of laws and regulations that should consist of the ideals of Indonesian law, the principles of the state based on the law, the principles of government based on the constitutional system and other principles, include also the principles of clear objectives, principles of enforceability, principles institutions, principles of proper content, principles of legal certainty, principles of implementing laws according to individual capabilities ${ }^{36}$."

According to Maria Farida Soeprapto, the principles of the formation of Indonesian legislation that should properly follow the guidelines and guidance include ${ }^{37}$ :

a. The ideals of Indonesian law which are not Pancasila (the precepts in that case apply as ideals (idee), which act as guide stars);

b. State Fundamental Norms are also none other than Pancasila (the precepts in that case apply as norms);

1997), p. 54 .

${ }^{33}$ Mustafa Abdullah, Op.cit., p. 73.

${ }^{34}$ Prodjohamidjojo Martiman, Memahami Dasar-dasar hukum Pidana Indonesia Bagian 2, (Bandung: Pradnya paramita,

${ }^{35}$ Item 133 Attachment II of Law Number 12 of 2011 concerning Formation of Invitation Laws

${ }^{36}$ A. Hamid Attamimi, 1990.

${ }^{37}$ Maria farida Indrati Soeprapto, 2007 
c. the principles of the state based on the law which places the law as a unique regulatory tool in the primacy of the law (der primat des rechts);

d. the principles of government based on a constitutional system that places the law as the basis and limits for the administration of government activities.

Whereas Article 5 of Law Number 12 Year 2011 concerning Formation of Regulations and Regulations states that in the form of Regulations of Legislation, it must be carried out based on the principles of Formation of good Regulations, including ${ }^{38}$ :
a. Clarity of purpose;
b. Appropriate institutional or forming authority;
c. Conformity between type, hierarchy and material content;
d. Can be implemented;
e. Usability and efficacy;
f. Clarity of formulation; and
g. Openness.

Based on the description above, what is essential to the existence of good Government Regulations is that there are principles for establishing good laws and regulations. The existence of the principle in Article 5 needs to be examined. This is simply because of the position of the principle as the heart of the legislation.

One important principle is the principle of conformity between type, hierarchy and material content. What is meant by the principle of conformity between types, hierarchy and material content is that in the Formation of Legislation Regulations must really pay attention to the appropriate content material, in accordance with the type and hierarchy of the Statutory Regulations ${ }^{39}$. Juridical consequences for the establishment of Government Regulation Number 24 of 2016 concerning Amendment to Government Regulation Number 37 of 1998 concerning Land Deed Official position regulations can be canceled because this government regulation was formed not in accordance with the basis of its authority delegated from other government regulations so that it cannot provide legal certainty. The impact of this government regulation can be revoked and declared invalid because it does not obey the principles of the formation of legislation.

A statutory regulation can only be revoked and declared invalid by legislation of the same or higher level. Revocation of the statutory regulations with higher legislation is intended to accommodate all or part of the more aggressive statutory material that has been revoked ${ }^{40}$.

\section{Conclusions}

The legal status of the delegation of authority from government regulations to other government regulations is invalid because government regulations are statutory regulations established by the President to carry out the law accordingly. This confirms the delegation of the formation of government regulations from higher laws (statutes) to lower (Government Regulations) to carry out the law, not to carry out other government regulation provisions.

Juridical consequences of the formation of Government Regulation Number 24 of 2016 concerning Amendment to Government Regulation Number 37 of 1998 concerning Land Deed Official Position Regulations that are formed not in accordance with statutory regulations according to state administration law is that it can be canceled because it was formed by delegation of inappropriate authority so that the regulations this government cannot provide legal certainty. The implication of this government regulation can be revoked because it does not comply with the principles of the formation of legislation.

\section{Recommendation}

In the formation of a statutory regulation, it is better to refer to the provisions in Law Number 12 of 2011 concerning the Formation of Laws and Regulations so that the resulting laws and regulations are in accordance with the principles of establishing good laws and regulations.

${ }^{38}$ Article 5 of Law Number 12 of 2011 concerning Formation of Regulations and Regulations.

${ }^{39}$ Elucidation of Article 5 letter c of Law Number 12 of 2011 concerning Formation of Regulations and Regulations

40 Articles 158 and 159 of Attachment II of Law Number 12 of 2011 concerning Formation of Regulations and 
Appropriate regulations for Land Deed Official office regulations according to Law Number 12 of 2011 concerning the Formation of Legislation is to enact laws concerning Land Deed Official Position Regulations in the context of carrying out provisions in Law Number 5 of 1960 concerning Basic Regulations Agrarian Principles. This should be done considering the Land Deed Official position is as important as the notary position. The Land Deed Official position requires a strong legal umbrella in carrying out its duties as a public official who is authorized to make authentic deeds regarding certain legal actions regarding Land Rights or Ownership Rights of Flats.

\section{Reference}

[1.] Departemen Hukum dan Hak Asasi Manusia RI Badan Pembinaan Hukum Nasional Pusat Penelitian dan Pengembangan Sistem Hukum Nasional, Laporan Ompendium Bidang Hukum Perundang-Undangan, Jakarta, 2008,

[2.] Bagir Manan, Pertumbuhan dan Perkembangan Konstitusi Suatu Negara, Mandar Maju, Bandung, 1995.

[3.] Article 1 number 5 of Law Number 12 of 2011 concerning Formation of Regulations and Regulations

[4.] CHAPTER II letter A number 198 Attachment II of Law Number 12 of 2011 concerning Formation of Regulations and Regulations.

[5.] CHAPTER II letter A number 199 Attachment II of Law Number 12 of 2011 concerning Formation of Regulations and Regulations.

[6.] Article 1, number 2 of Law 12 of 2011 concerning Formation of Regulations and Regulations.

[7.] Kamus Besar Bahasa Indonesia, Pusat Bahasa Indonesia.

[8.] Article 1 Number 23 of Law Number 30 Year 2014 concerning Government Administration

[9.] Maria Farida Indrati Soeprapto, Hal-hal Khusus Dalam Perundang-undangan, Jakarta, 2009.

[10.] Philipus M.Hadjon, 2005, Pengantar Hukum Administrasi Indonesia, (Introduction The Indonesian Administrative Law), Gadjah Mada University Press, Yogyakarta.

[11.] Bagir Manan, 2000, Wewenang Provinsi Kabupaten dan Kota Dalam Rangka Otonomi Daerah, Makalah Pada Seminar Nasional FH Unpad (Selajutnya disebut Bagir Manan V).

[12.] Kementrian Pendayaan Aparatur Negara, 2013, Naskah Akademik Undang-Undang Administrasi Pemerintah, Jakarta.

[13.] Jimly Asshiddiqie, 2006, Perihal Undang-Undang, Konstitusi Press Jakarta.

[14.] Article 12 of Law Number 12 of 2011 concerning Formation of the Formulation of Regulations and Regulations.

[15.] point 24 Appendix II of Law Number 12 of 2011 concerning Formation of Formation of Regulations and Regulations

[16.] Maria Farida Indrati Soeprapto, Ilmu Perundang-Undangan, Kanisius, Yogyakarta.

[17.] Hoesein, Zainal Arifin, Judicial Review di Mahkamah Agung RI (tiga dekade pengujian peraturan perundang-undangan), Jakarta:Rajawali Press,

[18.] Moeljatno. Pertanggung Jawab Pidana, Aksara Baru, Jakarta, 1987,

[19.] Kornelia A. Mandasari, "Pertanggungjawaban Pidana Tindak Pidana Terkait Pemberian Delegasi Kewenangan," Jurnal Mimbar Keadilan, vol. 14, no. 28, (Januari 2019):

[20.] Moeljatno, Asas-Asas Hukum Pidana, Rineka Cipta,Jakarta, 2008.

A. Zainal Abidin Farid, Hukum Pidana I, (Jakarta: Sinar Grafika, 1995),

[21.] Leden Marpaung, Unsur-Unsur Perbuatan Yang Dapat Dihukum, (Jakarta: 1991, Sinar Grafika,1991),

[22.] Roeslan Saleh, Perbuatan Pidana Dan Pertanggungjawaban Pidana, Dua pengertian Dasar Dalam Hukum Pidana, cetakan ketiga, (Jakarta: Aksara Baru, 1983),

[23.] Muladi, dkk, Demokratisasi Hak Asasi manusia Dan reformasi Hukum Di Indonesia, (Jakarta: The Habibie Center, 2002),

[24.] Mustafa Abdullah, dkk, Intisari Hukum Pidana, (Jakarta: Ghalia Indonesia, 1983),. 
[25.] Prodjohamidjojo Martiman, Memahami Dasar-dasar hukum Pidana Indonesia Bagian 2, (Bandung: Pradnya paramita, 1997),

[26.] Item 133 Attachment II of Law Number 12 of 2011 concerning Formation of Invitation Laws

A. Hamid Attamimi, 1990.

[27.] Maria farida Indrati Soeprapto, 2007

[28.] Article 5 of Law Number 12 of 2011 concerning Formation of Regulations and Regulations.

[29.] Elucidation of Article 5 letter c of Law Number 12 of 2011 concerning Formation of Regulations and Regulations

[30.] Articles 158 and 159 of Attachment II of Law Number 12 of 2011 concerning Formation of Regulations and Regulations. 